96

Kushner, D. J. \& Lisson, T. A. (1959). J. gen. Microbiol. 21, 96-108

\title{
Alkali Resistance in a Strain of Bacillus cereus Pathogenic for the Larch Sawfly Pristiphora erichsonii
}

\author{
By D. J. KUSHNER AND T. A. LISSON \\ Forest Insect Laboratory, Sault Ste. Marie, Ontario, Canada
}

SUMMARY: Upon repeated subculture in media of gradually increasing $\mathrm{pH}$ value a strain of Bacillus cereus developed the ability to grow under strongly akaline conditions. Organisms with the highest alkali resistance could grow at $\mathrm{pH} 10 \cdot 3$, and stocks of intermediate resistance were also obtained. When growing on alkaline agar, resistant bacteria underwent marked morphological changes. In liquid media, the bacteria retained the ability to synthesize lecithinase. Resistance was not lost upon several transfers on a neutral medium.

Resistant bacteria when growing in alkaline media caused a rapid decrease in pH value. A similar pH decrease was caused by sensitive bacteria in media of the highest degree of alkalinity in which they could grow. The decline of $\mathrm{pH}$ value accompanied, but did not precede, growth; acid production by the resistant bacteria does not appear to be a primary mechanism of resistance.

Most bacterial species grow best in media of a relatively restricted $\mathrm{pH}$ range, near neutrality. Topley and Wilson's Principles (1955) stated that, with few exceptions, human pathogens grow in the range $\mathrm{pH} 5 \cdot 0-8 \cdot 0$. To the extent that the $\mathrm{pH}$ range for growth of other bacterial species has been studied, there appear to be few major deviations from these figures. The most striking, on the acid side, is that of Thiobacillus thiooxidans, which can grow in ' $5-7 \%$ ' $\mathrm{H}_{2} \mathrm{SO}_{4}$ (Umbreit, 1951). On the alkaline side, Streptococcus faecalis was reported to grow up to $\mathrm{pH} 11$, as well as in strongly acid media (Downie \& Cruickshank, 1928). The effect of the $\mathrm{pH}$ value of the medium on the growth of Bacillus cereus Fr. \& Fr. is one of the factors governing the pathogenicity of this organism for insects. In recent discussions of this subject (Heimpel, 1955 $a$; Heimpel \& Angus, 1958) it was pointed out that $B$. cereus ingested by mouth is a pathogen of larvae of the codling moth, Carpocapsa pomonella L. (Stephens, 1952), and of the larch sawfly, Pristiphora erichsoni Htg. (Heimpel, 1954), but not of the forest tent caterpillar, Malacosoma disstria $\mathrm{Hbn}$. In the first two insects the midgut $\mathrm{pH}$ value is near neutrality and within the growth range of normal $\boldsymbol{B}$. cereus. In the last organism, however, the midgut is at $\mathrm{pH} 9 \cdot 5-10 \cdot 5$, a range outside that in which $\boldsymbol{B}$. cereus usually grows.

The work described here arose from an attempt to increase the host range of micro-organisms which infect insects. For Bacillus cereus to cause disease in insect larvae the following sequence of events appears necessary: the bacteria or their spore must be swallowed; the spores, when present, must germinate; and the vegetative organisms must grow and damage the insect, possibly by lecithinase production (Heimpel, 1955b; Kushner \& Heimpel, 1957). By whatever mechanism the bacteria kill the insect, in most cases it is likely that 
they must first multiply inside it. Surveys of internal $\mathrm{pH}$ values of insects (Staudenmayer, 1940; Waterhouse, 1949) show that the larvae of several species of phytophagous lepidopterous insects have, as does the forest tent caterpillar, highly alkaline midgut contents. Alkaline midgut conditions have also been observed in the Trichoptera and in some species of Coleoptera. Although $B$. cereus, as well as many other bacteria, would not normally be expected to grow in these insects, it seemed possible that bacteria induced to grow under more alkaline conditions than usual might be able to grow in these insects and perhaps to kill them. As a first step in this work, we have produced an alkali-resistant strain of $\boldsymbol{B}$. cereus, which is able to grow in media of higher $\mathrm{pH}$ value than can the parent strain.

\section{METHODS}

Organisms. Bacillus cereus, strain Mu-3055, a pathogen of the larch sawfly (Heimpel, 1955b), was used throughout this study.

Growth media. Buffered growth media were used in all experiments, the buffer concentrations chosen being the highest that would permit maximal bacterial growth. The following media were prepared:

(1) Nutrient broth + phosphate buffer. Phosphate buffer (0.1 M, pH 7.5) was prepared by dissolving $71 \cdot 6 \mathrm{~g} . \mathrm{Na}_{2} \mathrm{HPO}_{4} \cdot \mathbf{1 2 H}_{2} \mathrm{O}$ in water, adding $\mathbf{3 \cdot 2} \mathrm{ml}$. conc. $\mathrm{HCl}$, and bringing the volume to $2 \mathrm{l}$. with water. Dried nutrient broth (Difco) was dissolved in this to $8 \mathrm{~g} . /$. The final $\mathrm{pH}$ value was $7 \cdot 4$.

(2) Nutrient broth + tris buffer. A $0 \cdot 05$ m solution of 2-amino-2-hydroxymethylpropane-1:3 diol (tris: $\mathrm{pH} 7 \cdot 5$ ) was prepared by dissolving $12 \cdot 1 \mathrm{~g}$. tris in water, adding $6.25 \mathrm{ml}$. conc. $\mathrm{HCl}$, and diluting to $2 \mathrm{l}$. Nutrient broth (dried, Difco) was made up in this, as for medium no. 1 , the final $\mathbf{p H}$ value being $\mathbf{7 \cdot 5}$.

(3) Casein hydrolysate + tris buffer. A 2\%(w/v) solution of 'Enzymatic Casein Hydrolysate' (Nutritional Biochemicals Co., Cleveland, Ohio, U.S.A.) was made in tris buffer solution as in medium no. 2 . The final $\mathrm{pH}$ value was $7 \cdot 5$.

(4) Buffered nutrient agar. Nutrient agar (Difco) was dissolved in 0.1 Mphosphate buffer; or $1.5 \%(\mathrm{w} / \mathrm{v})$ 'Bacto Agar' (Difco) was made up in nutrient broth + phosphate buffer.

For most of this work the liquid media were dispensed in $10 \mathrm{ml}$. lots in 1 in. $\times 8$ in. culture tubes and autoclaved at $15 \mathrm{lb}$./sq.in. for $15 \mathrm{~min}$. Immediately before use, the $\mathrm{pH}$ value of a tube of medium was brought to the desired level by adding $\mathrm{N}-$ or $10 \mathrm{~N}-\mathrm{NaOH}$, as given by previously determined titration curves. The buffered agar was sterilized in 5 or $10 \mathrm{ml}$. lots in screwcap tubes. For use, the agar was re-melted by immersing the tubes in a hot water bath, and $\mathrm{NaOH}$ was added before making slopes or pouring plates. Addition of $\mathrm{NaOH}$ after sterilizing was necessary since autoclaving strongly alkaline media led to charring. It was necessary, furthermore, to adjust the $\mathrm{pH}$ value of each tube just before use, since these media do not maintain a high $\mathrm{pH}$ value indefinitely. The extent of the decrease in $\mathrm{pH}$ value observed when different samples of sterile alkaline media were shaken at $37^{\circ}$ is shown in Table 1. Alkaline casein hydrolysate + tris buffer medium was the most stable 
and alkaline nutrient broth + tris buffer medium the least so. Media of $\mathrm{pH} 8.0$ or less did not change $\mathrm{pH}$ value on incubation in the absence of bacteria. The chemical changes which caused the $\mathrm{pH}$ to decrease were not investigated, but $\mathrm{CO}_{2}$ absorption was probably involved.

Table 1. Fall of $\mathrm{pH}$ in sterile alkaline media incubated at $37^{\circ}$

\begin{tabular}{|c|c|c|c|c|c|}
\hline \multirow{3}{*}{$\begin{array}{l}\text { Time } \\
\text { (hr.) }\end{array}$} & \multicolumn{5}{|c|}{$\mathrm{pH}$} \\
\hline & $\begin{array}{c}\text { Nutrient } \\
\text { broth }+ \text { phosphate }\end{array}$ & & $\begin{array}{r}\text { Nut } \\
\text { brotl }\end{array}$ & $\begin{array}{l}\text { trient } \\
\mathrm{a}+\text { tris }\end{array}$ & $\begin{array}{c}\text { Casein } \\
\text { hydrolysate }+ \text { tris }\end{array}$ \\
\hline & $\begin{array}{llll}9.36 & 9.84 & 10 \cdot 39\end{array}$ & $9 \cdot 48$ & $10 \cdot 00$ & $10.51 \quad 11 \cdot 05$ & $\begin{array}{llll}9.61 & 10.00 & 10.47\end{array}$ \\
\hline 10 & $\begin{array}{llll}9.22 & 9.72 & 10 \cdot 38\end{array}$ & $9 \cdot 36$ & $9 \cdot 77$ & $10 \cdot 18 \quad 10 \cdot 70$ & $\begin{array}{lll}9.50 & 9.99 & 10.34\end{array}$ \\
\hline 20 & $\begin{array}{lll}9.05 & 9.47 & 10.01\end{array}$ & $3 \cdot 28$ & $9 \cdot 51$ & $9.74,10.08$ & 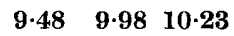 \\
\hline 30 & $\begin{array}{lll}9.03 & 9.37 & 10.01\end{array}$ & $9 \cdot 23$ & $9 \cdot 52$ & $\begin{array}{lll}9.72 & 10 \cdot 02\end{array}$ & $9 \cdot 85 \quad 10 \cdot 15$ \\
\hline
\end{tabular}

In following bacterial growth the culture tubes were shaken on a rotary shaker in an incubator at $37^{\circ}$. The rate of shaking was 160 cycles $/ \mathrm{min}$. and each tube moved in a circle of diameter 2 in. Growth was measured directly in the culture tubes as turbidity, the changes in optical density at $650 \mathrm{~m} \mu$ being followed by a Beckman Model DU spectrophotometer fitted with a test-tube adapter. In this system an optical density of 1.0 corresponded to $0.32 \mathrm{mg}$. dry wt. bacteria $/ \mathrm{ml}$. or to $8 \times 10^{7}$ viable bacteria $/ \mathrm{ml}$. as measured by plate counts. All figures given are corrected for the turbidity caused by the inoculum itself.

Measurements of $\mathrm{pH}$ value were made with a Beckman Model $\mathrm{G}$ pH meter and a glass electrode. Lecithinase activity was measured as previously described (Kushner, 1957).

\section{RESULTS}

\section{Development of alkali resistance}

In nutrient broth + phosphate buffer $9 \cdot 5$ was the highest $\mathrm{pH}$ value at which Bacillus cereus $\mathbf{M u - 3 0 5 5}$ grew, and there was an extended lag period before growth began (Fig. 2). The organism was induced to grow readily at $\mathrm{pH}$ values of 9.5 or higher by repeated subculture in media of increasing alkalinity, as follows: a 24 hr. culture of $B$. cereus, which had been maintained routinely on nutrient agar, was inoculated into a tube of nutrient broth + phosphate buffer, $\mathrm{pH} \mathbf{7 \cdot 4}$, and incubated with shaking until an optical density of about 1.0 was reached. One-half $\mathrm{ml}$. of this culture was then placed in each of a series of tubes at graded $\mathrm{pH}$ values from 7·4 up. After shaking for 8-12 hr., the tube of highest $\mathrm{pH}$ value showing growth comparable to that found in the tube of $\mathrm{pH} \mathrm{7.4}$ was selected for subculture in a series of tubes of the same and higher $\mathrm{pH}$ values. The process was continued, selecting each time bacteria from the tube of highest $\mathrm{pH}$ value showing vigorous growth. When necessary, serial subculture at the highest $\mathrm{pH}$ value possible was continued until the bacteria had acquired the ability to grow at a slightly higher $\mathrm{pH}$ value.

The course of a typical procedure is shown in Fig. 1 . It is seen that the bacteria were quickly induced to grow readily at $\mathrm{pH} 9 \cdot 5$, but the ability to 
grow in media of higher $\mathrm{pH}$ developed much more slowly. Bacteria had to be serially subcultured several times at each $\mathrm{pH}$ increment before they showed any increased alkali resistance. Even with numerous subcultures the resistant Bacillus cereus could not be induced to grow in broth of $\mathrm{pH}$ value greater than $10 \cdot 3$.

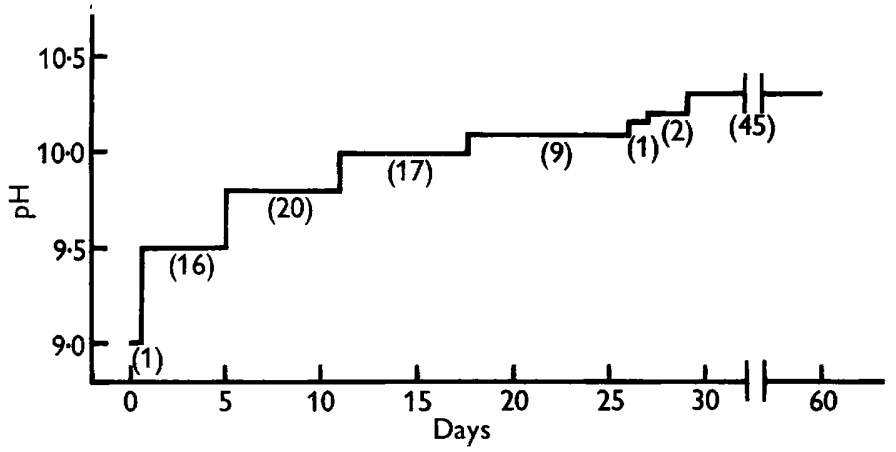

Fig. 1. Development of alkali resistance in Bacillus cereus. The time during which subcultures at each $\mathrm{pH}$ were carried out is shown on the abscissa. The actual number of subcultures at each $\mathrm{pH}$ is shown in parentheses in the figure.

After the bacteria had begun to grow at the higher $\mathrm{pH}$ values, subcultures were continued at intermediate values from $\mathrm{pH} \mathrm{9.5} \mathrm{up.} \mathrm{This} \mathrm{was} \mathrm{essential,}$ since it was frequently found that bacteria which at first grew well at the highest $\mathrm{pH}$ value tested died out after several subcultures at the same $\mathrm{pH}$ value. In these cases, it was necessary to continue the 'inducing' process with bacteria 'established' at a slightly lower $\mathrm{pH}$ value.

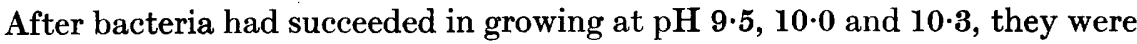
spread on buffered nutrient agar plates of these $\mathrm{pH}$ values and maintained by transfer every few days on alkaline plates or slopes. Normal bacteria were also maintained on buffered nutrient agar at $\mathrm{pH} \mathrm{7.4}$ and were used as 'sensitive bacteria' in subsequent experiments. As was expected, normal bacteria, unable to grow in alkaline liquid media, were also unable to grow on alkaline agar plates. Resistant bacteria have been maintained in our laboratory for periods of up to one year.

Nutrient broth + phosphate buffer was used in all cases as a medium for inducing alkali resistance in the bacteria whose properties are described here. Preliminary experiments showed that with subculture in casein hydrolysate + tris buffer medium of gradually increasing $\mathrm{pH}$ values alkali resistance was acquired in approximately one-third the time, though the degree of resistance reached was no higher.

\section{Colony formation and morphology of resistant organisms}

On alkaline agar the resistant cultures grew more slowly than they (or sensitive organisms) grew on neutral agar. The colonies were smaller than those of normal Bacillus cereus $\mathrm{Mu-3055}$ grown for the same length of time, but otherwise they appeared the same. The total quantity of bacteria growing when 
resistant organisms were spread on an alkaline plate was relatively small. When resistant organisms were grown on nutrient agar at $\mathrm{pH} 7 \cdot 4$ there was no apparent difference between their growth and that of normal $B$. cereus.

Microscopically, resistant bacteria growing on alkaline agar exhibited marked morphological changes. The presence of the buffer itself caused no such change; sensitive bacteria grown on buffered nutrient agar at $\mathrm{pH} 7 \cdot 4$ appeared the same as those growing on unbuffered agar. The resistant bacteria growing at $\mathbf{p H ~ 9 . 5}$ had an appearance only slightly different from that of sensitive bacteria; the cells were a little thinner and some were longer than those of sensitive cultures. The decrease in cellular diameter was more marked in bacteria growing at $\mathrm{pH} \mathbf{1 0 \cdot 3}$ and the organisms differed considerably in length.

When resistant organisms from plates at $\mathrm{pH} 10 \cdot 3$ were subcultured at $\mathrm{pH} \mathbf{7 \cdot 4}$ the organisms appeared microscopically like normal Bacillus cereus and formed spores. As will be seen below, resistant organisms retained their alkali resistance when grown at $\mathrm{pH} 7 \cdot 4$. There is a possibility that resistance may be transmitted through the spores; this has not yet been investigated.

\section{Growth of sensitive and resistant bacteria in alkaline liquid media}

The effect of $\mathrm{pH}$ value on the growth of sensitive and alkali-resistant organisms in nutrient broth + phosphate buffer is shown in Fig. 2. Measurements of the maximal growth rates and final bacterial concentrations obtained in this and other similar experiments are given in Table 2. In this type of experiment, the inocula consisted of equal quantities of sensitive or resistant

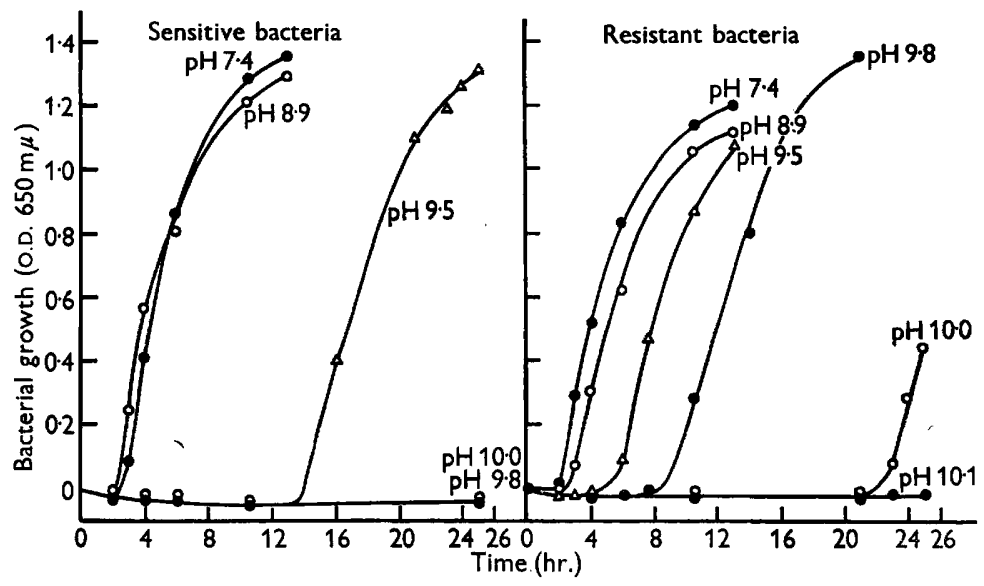

Fig. 2. The effect of $\mathrm{pH}$ on growth of sensitive and resistant bacteria in liquid medium. Nutrient broth + phosphate buffer was used. The initial $\mathrm{pH}$ of each tube is shown in the figure. The resistant bacteria had been maintained on agar of $\mathrm{pH} 10 \cdot 3$. The inoculum used of sensitive or resistant bacteria was $0.36 \mathrm{mg}$.

bacteria from agar plates (18-24 $\mathrm{hr}$. culture), washed twice with distilled water before being added to broth tubes. The actual weights of bacteria added in each experiment were as given; the volume of bacterial suspension used varied with the bacterial concentrations but was in no case greater than $0 \cdot 10 \mathrm{ml}$. 
Resistant bacteria from alkaline agar plates were used in the first experiments. Once it was found, however, that resistant bacteria retained their resistance when grown on neutral medium (see below), neutral agar plates were used in certain specified experiments for preparing inocula of resistant organisms.

Differences in $\mathrm{pH}$ range for growth as between sensitive and resistant bacteria are immediately apparent (Fig. 2). At pH 7.4 the lag period for growth of both sensitive and resistant organisms was approximately the same and this was found in practically all experiments. The sensitive bacteria grew at pH 9.5 only after a lag period of $14 \mathrm{hr}$. and grew at no higher pH during a $25 \mathrm{hr}$. period. Sensitive bacteria did not grow at $\mathrm{pH} 10.0$ in experiments lasting $30 \mathrm{hr}$. or more. The resistant bacteria, however, grew at $\mathrm{pH} 9.5 \mathrm{after}$ a $4 \mathrm{hr}$. lag

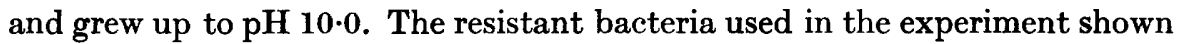
in Fig. 2 had originally grown at $\mathrm{pH} \mathrm{10.3} \mathrm{in} \mathrm{liquid} \mathrm{media} \mathrm{before} \mathrm{subculture} \mathrm{on}$ alkaline agar. A small loss of resistance, therefore, occurred upon transfer to agar, or possibly upon washing the organisms.

Table 2. Growth rates and final bacterial concentrations attained by sensitive and alkali-resistant bacteria in nutrient broth + phosphate buffer of different initial $\mathrm{pH}$ values

\begin{tabular}{|c|c|c|c|c|}
\hline Expt. & Bacteria & pH & $\begin{array}{l}\text { Maximal } \\
\text { growth } \\
\text { rate } \\
\text { (o.D./hr.) }\end{array}$ & $\begin{array}{c}\text { Maximal } \\
\text { bacterial } \\
\text { concentration } \\
\text { (o.D.) }\end{array}$ \\
\hline \multirow[t]{2}{*}{1} & Sensitive & $\begin{array}{l}7 \cdot 4 \\
8 \cdot 9 \\
9 \cdot 5\end{array}$ & $\begin{array}{l}0 \cdot 253 \\
0 \cdot 193 \\
0 \cdot 140\end{array}$ & - \\
\hline & Resistant & $\begin{array}{r}7 \cdot 4 \\
8 \cdot 9 \\
9 \cdot 5 \\
10 \cdot 0\end{array}$ & $\begin{array}{l}0 \cdot 183 \\
0 \cdot 180 \\
0 \cdot 150 \\
0 \cdot 187\end{array}$ & $\frac{-}{-}$ \\
\hline \multirow[t]{2}{*}{2} & Sensitive & $\begin{array}{l}7 \cdot 4 \\
9 \cdot 3\end{array}$ & $\begin{array}{l}0 \cdot 226 \\
0 \cdot 210\end{array}$ & $\begin{array}{l}1.46 \\
1.24\end{array}$ \\
\hline & Resistant & $\begin{array}{l}7 \cdot 4 \\
9 \cdot 3\end{array}$ & $\begin{array}{l}0 \cdot 266 \\
0 \cdot 188\end{array}$ & $\begin{array}{l}1 \cdot 41 \\
1 \cdot 30\end{array}$ \\
\hline $\mathbf{3}$ & Resistant & $\begin{array}{l}7 \cdot 4 \\
9 \cdot 3\end{array}$ & $\begin{array}{l}0 \cdot 234 \\
0.204\end{array}$ & $\begin{array}{l}1 \cdot 42 \\
1 \cdot 35\end{array}$ \\
\hline \multirow[t]{2}{*}{4} & Sensitive & $\begin{array}{l}7 \cdot 4 \\
9 \cdot 5\end{array}$ & $\begin{array}{l}0.350 \\
0.253\end{array}$ & - \\
\hline & Resistant & $\begin{array}{l}7 \cdot 4 \\
9 \cdot 5\end{array}$ & $\begin{array}{l}0 \cdot 306 \\
0 \cdot 285\end{array}$ & - \\
\hline
\end{tabular}

The maximal growth rate was taken as the rate of increase in optical density between o.D. $0 \cdot 100-0 \cdot 700$.

Rates in Expt. 1 are from the experiment illustrated in Fig. 2. Figures for maximal bacterial concentration were obtained $15-20 \mathrm{hr}$. after growth began.

Weight of inocula : Expt. 1, 0.36 mg.; Expts. 2 and 3, 0.10 mg.; Expt. 4, 0.30 mg.

As indicated in Fig. 2, in media of high pH before the onset of growth there was a slight decrease in optical density. This suggests that under strongly alkaline conditions some lysis of bacteria occurred.

The measurements given in Table 2 show that, despite variations from one experiment to another, sensitive and resistant bacteria in general grew at 
closely comparable rates at $\mathrm{pH} 7 \cdot 4$. Raising the $\mathrm{pH}$ tended to decrease the maximal growth rate to a varying degree; but even at the highest initial $\mathrm{pH}$ growth, if it occurred at all, proceeded relatively rapidly. The word 'initial' is stressed because, as will be seen, bacteria growing in the buffered alkaline media used here caused a rapid decrease in the $\mathrm{pH}$ value. An accurate estimate of the considerable effect of $\mathrm{pH}$ on growth rate can only be obtained if the initial $\mathrm{pH}$ is held constant by frequent additions of alkali.

Little difference was noted between the maximal concentrations reached by both sensitive and resistant bacteria (Table 2). In nutrient broth + phosphate buffer maximal growth was reached at an optical density of 1.3-1.4. In the other media used there was a slightly higher maximal optical density $(1 \cdot 5-1 \cdot 6)$. Maximal growth rates were similar to those found in nutrient broth + phosphate buffer.

Table 3. Effect of $\mathrm{pH}$ on growth of alkali-sensitive and resistant bacteria in different media

\begin{tabular}{|c|c|c|c|c|c|c|c|c|}
\hline \multirow[b]{2}{*}{ Medium } & \multirow{2}{*}{$\begin{array}{c}\text { Duration } \\
\text { of } \\
\text { expt. } \\
\text { (hr.) }\end{array}$} & \multirow{2}{*}{$\begin{array}{l}\text { Bacteria } \\
\text { in } \\
\text { inoculum } \\
\text { (mg.) }\end{array}$} & & & \multicolumn{2}{|c|}{$T_{0.4}(\mathrm{hr}.) \dagger$} & \multicolumn{2}{|c|}{ Final pH } \\
\hline & & & Initis & pH* & Sensitive & Resistant & Sensitive & Resistant \\
\hline $\begin{array}{l}\text { Nutrient } \ddagger \\
\text { broth }+ \\
\text { phosphate }\end{array}$ & 25 & $0 \cdot 36$ & $\begin{array}{r}7 \cdot 4 \\
8 \cdot 9 \\
9 \cdot 5 \\
9 \cdot 8 \\
10 \cdot 0 \\
10 \cdot 1\end{array}$ & & $\begin{aligned} & 4 \cdot 0 \\
& 3 \cdot 5 \\
& 16 \cdot 0 \\
> & 25 \\
> & 25 \\
> & 25\end{aligned}$ & $\begin{array}{r}3 \cdot 5 \\
5 \cdot 0 \\
7 \cdot 2 \\
11 \cdot 0 \\
24 \cdot 8 \\
>\mathbf{2 5}\end{array}$ & $\begin{array}{l}7 \cdot 5 \\
8 \cdot 2 \\
8 \cdot 3 \\
9 \cdot 2 \\
9 \cdot 4 \\
9 \cdot 5\end{array}$ & $\begin{array}{l}7 \cdot 5 \\
8 \cdot 2 \\
8 \cdot 3 \\
8 \cdot 5 \\
8 \cdot 7 \\
9 \cdot 5\end{array}$ \\
\hline $\begin{array}{l}\text { Nutrient } \\
\text { broth + tris } \\
\text { buffer }\end{array}$ & $2 \pi$ & $0 \cdot 36$ & $\begin{array}{r}7 \cdot 5 \\
9 \cdot 2 \\
9 \cdot 5 \\
9 \cdot 8 \\
10 \cdot 0 \\
10 \cdot 2 \\
10 \cdot 5 \\
10 \cdot 9 \\
11 \cdot 2\end{array}$ & $\begin{array}{l}(9 \cdot 5) \\
(9 \cdot 6) \\
(9 \cdot 9)\end{array}$ & $\begin{array}{r}2 \cdot 5 \\
3 \cdot 2 \\
4 \cdot 5 \\
9 \cdot 2 \\
15 \cdot 0 \\
22 \cdot 5 \\
25 \cdot 0 \\
>27 \\
>27\end{array}$ & $\begin{array}{r}2 \cdot 7 \\
4 \cdot 0 \\
5 \cdot 5 \\
6 \cdot 2 \\
7 \cdot 0 \\
10 \cdot 5 \\
13 \cdot 5 \\
19 \cdot 0 \\
>\mathbf{2 7}\end{array}$ & $\begin{array}{l}7 \cdot 7 \\
8 \cdot 6 \\
8 \cdot 7 \\
8 \cdot 7 \\
8 \cdot 8 \\
9 \cdot 0 \\
9 \cdot 2 \\
9 \cdot 7 \\
9 \cdot 8\end{array}$ & $\begin{array}{l}7 \cdot 9 \\
8 \cdot 7 \\
8 \cdot 8 \\
8 \cdot 9 \\
8 \cdot 9 \\
9 \cdot 0 \\
9 \cdot 0 \\
8 \cdot 9 \\
9 \cdot 8\end{array}$ \\
\hline $\begin{array}{l}\text { Casein } \\
\text { hydrolysate } \\
\text { buffer }\end{array}$ & $\begin{array}{r}25 \\
+ \text { tris }\end{array}$ & $0 \cdot 28$ & \begin{tabular}{r|}
$7 \cdot 4$ \\
$8 \cdot 9$ \\
$9 \cdot 4$ \\
$9 \cdot 8$ \\
$10 \cdot 0$ \\
$10 \cdot 3$
\end{tabular} & $\begin{array}{l}(9 \cdot 7) \\
(9 \cdot 9) \\
(10 \cdot 2)\end{array}$ & $\begin{array}{r}2 \cdot 5 \\
3 \cdot 2 \\
4 \cdot 6 \\
25 \cdot 0 \\
>25 \\
>25\end{array}$ & $\begin{aligned} 2 \cdot 8 \\
3 \cdot 4 \\
5 \cdot 2 \\
16 \cdot 0 \\
17 \cdot 0 \\
>25\end{aligned}$ & $\begin{array}{r}8 \cdot 1 \\
8 \cdot 7 \\
8 \cdot 9 \\
9 \cdot 7 \\
9 \cdot 9 \\
10 \cdot 2\end{array}$ & $\begin{array}{r}8 \cdot 1 \\
8 \cdot 6 \\
8 \cdot 9 \\
9 \cdot 2 \\
9 \cdot 3 \\
10 \cdot 1\end{array}$ \\
\hline
\end{tabular}

Resistant bacteria as in Fig. 2 ; organisms growing in casein hydrolysate + tris buffer had been subcultured at $\mathrm{pH} 7 \cdot 4$ before use.

* Figures in parentheses show final pH after incubation in the absence of bacteria.

$\dagger$ Time at which cultures reach a (net) optical density of $0 \cdot 4$.

The results given are those illustrated in Fig. 2.

In these experiments the most striking and consistent effects of the $\mathrm{pH}$ value of the medium were those produced on the lag period. Growth curves can conveniently be described in terms of this figure or, more accurately, in terms of the time necessary for the bacteria to reach a defined net optical density. Here, the value $T_{0 \cdot 4}$, that is the time at which an optical density of $0 \cdot 4$ is reached, is used to describe bacterial growth. The $\boldsymbol{T}_{0^{\circ} 4}$ values for the curves shown in Fig. 2 are given, with other data, in Table 3. 
The pattern of growth of sensitive and resistant organisms in nutrient broth + tris buffer medium and in casein hydrolysate + tris buffer medium was similar to that found in nutrient broth + phosphate buffer (Table 3). Both sensitive and resistant organisms grew at a slightly higher initial $\mathrm{pH}$ range in nutrient broth + tris buffer medium than in the other two media. This was probably due to the more rapid spontaneous decrease of $\mathrm{pH}$ value found in the nutrient broth + tris buffer medium (Tables 1 and 3). In these experiments, sensitive bacteria were compared with bacteria maintained at $\mathrm{pH} 10 \cdot 3$. Resistant cultures maintained on buffered agar plates at $\mathrm{pH}$ values between $7 \cdot 4$ and $10.3 \mathrm{had}$, as was expected, intermediate resistance in liquid media. As the figures in Table 4 show, organisms from nutrient agars of progressively increasing $\mathrm{pH}$ values showed progressive shortening of the $T_{0 \cdot 4}$ value in alkaline media. Within the weight range used in these experiments, altering the size of inoculum had little effect on the growth. It was found, in addition, that decrease of inoculum size from equivalent $0.30-0.02 \mathrm{mg}$. dry wt./tube increased the lag period and the $T_{0 \cdot 4}$ value by about $25 \%$ at all $\mathrm{pH}$ values tested; increase of inoculum size, up to equivalent $1 \mathrm{mg}$. dry wt./tube had relatively little effect.

Table 4. Effect of $\mathrm{pH}$ on growth of bacteria of varying degrees of resistance in liquid medium

\begin{tabular}{|c|c|c|c|}
\hline \multirow{2}{*}{$\begin{array}{l}\mathrm{pH} \text { of } \\
\text { medium }\end{array}$} & \multicolumn{3}{|c|}{$\begin{array}{l}T_{0 \cdot 4}(\mathrm{hr} .) \\
\text { Bacteria from agar of } \mathrm{pH}\end{array}$} \\
\hline & $7 \cdot 4$ & $9 \cdot 5$ & $10 \cdot 3$ \\
\hline $7 \cdot 4$ & $3 \cdot 0$ & $3 \cdot 6$ & $2 \cdot 8$ \\
\hline $9 \cdot 4$ & $>12$ & $7 \cdot 3$ & $5 \cdot 0$ \\
\hline $9 \cdot 9$ & $>12$ & $>12$ & $11 \cdot 0$ \\
\hline
\end{tabular}

A $0.34 \mathrm{mg}$. inoculum of bacteria was used in all tubes. Growth medium was nutrient broth + phosphate buffer.

\section{Acid production by sensitive and resistant bacteria}

Both sensitive and resistant bacteria growing in media at $\mathrm{pH} 8.9$ or higher caused the $\mathrm{pH}$ value of the medium to fall (Table 3). In nutrient broth + phosphate buffer ( $\mathrm{pH} \mathrm{7.4)}$ no change in the $\mathrm{pH}$ value occurred with growth; in tris-buffered media ( $\mathrm{pH} 7 \cdot 4-7 \cdot 5$ ) growth caused a small increase in $\mathrm{pH}$ value. When the organisms did not grow, the $\mathrm{pH}$ value of alkaline media fell only to the same extent as in media to which no bacteria were added (Tables 1 and 3).

Acid production was in some cases quite vigorous; the decreases in $\mathrm{pH}$ value which took place indicate that the growing bacteria produced 0.1-0.3 m-equiv. acid (corresponding to $0 \cdot 1-0 \cdot 3 \mathrm{ml}$. $\mathrm{N}$-acid). The actual acid(s) produced were not determined. Possibly, as with Escherichia coli (Gale, 1948), Bacillus cereus Mu-3055 growing in alkaline media lowered the $\mathrm{pH}$ by deaminating some of the amino acids present and forming carboxylic acids.

The relation between acid production and the phase of bacterial growth is of importance in considering possible mechanisms of alkali resistance. This 
relation was studied in the experiments illustrated in Fig. 3 in which the growth of resistant cultures and the $\mathrm{pH}$ changes were followed simultaneously. Before growth began the $\mathrm{pH}$ values of the medium declined slowly, the rate of decline being equal to the spontaneous rate already described (Table 1). After the onset of growth, the $\mathrm{pH}$ value fell much more rapidly and continued to fall while growth continued. When the $\mathrm{pH}$ of the medium was not permitted to fall freely but was held constant by periodic additions of $\mathrm{NaOH}$ solution, the resistant cultures still grew. The rate of growth was somewhat lower at $\mathrm{pH} \mathbf{9 \cdot 4}$, and considerably lower at $\mathrm{pH} 9 \cdot 8$, than in media in which the $\mathrm{pH}$ value was permitted to fall. Significant growth did take place when the $\mathrm{pH}$ was held at $\mathbf{9 \cdot 8 .}$

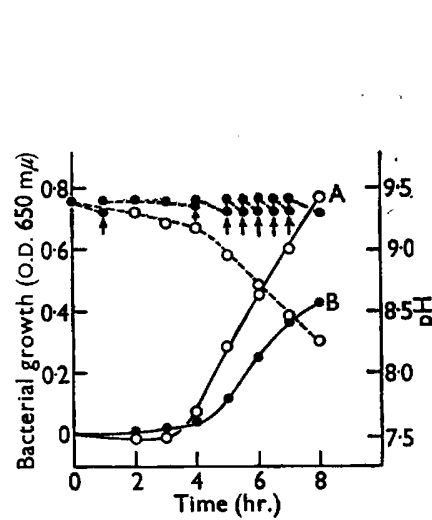

$a$

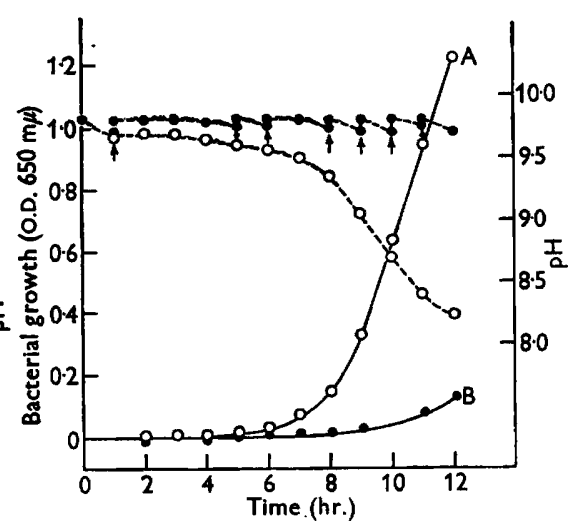

b

Figs. $3 a, b$. Growth of resistant bacteria in alkaline media of varying and constant pH. Solid lines represent bacterial growth, and broken lines represent the $\mathrm{pH}$ of the medium. Curves $\boldsymbol{A}$ show bacterial growth that took place when the $\mathrm{pH}$ fell freely, and curves $B$ the growth that took place when the $\mathrm{pH}$ was held at the initial value by periodic additions of $\mathrm{NaOH}$ (indicated by arrows). Bacillus cereus resistant to growth on agar of $\mathrm{pH} 10 \cdot 3$ was subcultured at $\mathrm{pH} 7 \cdot 4$, before use; $1.2 \mathrm{mg}$. inocula were placed in $200 \mathrm{ml}$. lots of nutrient broth + phosphate buffer in $500 \mathrm{ml}$. Erlenmeyer flasks, incubated with shaking, and samples taken at the times indicated for $\mathrm{pH}$ and optical density readings. (a) Initial pH of $9 \cdot 4$. (b) Initial $\mathrm{pH}$ of $9 \cdot 8$.

In an experiment similar to that shown in Fig. $3 a$ an inoculum of $4 \cdot 2 \mathrm{mg}$. resistant organisms was used. The rate of $\mathrm{pH}$ change relative to growth was the same. The organisms used in the experiment shown in Fig. 3 had been subcultured once at $\mathrm{pH} 7 \cdot 4$. Resistant bacteria taken directly from agar of $\mathrm{pH} 10 \cdot 3$ caused the same rate of fall of $\mathrm{pH}$ when grown on liquid medium of pH 9.5.

The relation between growth phase and acid production by sensitive organisms multiplying in nutrient broth + phosphate buffer at $\mathrm{pH} \mathrm{9.4}$ was similar to that found in the resistant cultures. The $\mathrm{pH}$ value remained almost constant during the prolonged lag phase and fell rapidly when growth began (Fig. 4). Comparison of Fig. $3 a$ with Fig. 4 shows that the rate of $\mathrm{pH}$ decline caused by growing sensitive organisms was similar to that caused by growing resistant organisms. Between $\mathrm{pH} \mathbf{9 \cdot 0}$ and $\mathbf{8 \cdot 5}$, when the bacteria were growing at the maximum rate, the respective rates of $\mathrm{pH}$ decline were identical. 


\section{Stability of alkali resistance}

That alkali resistance was not lost when resistant organisms were subcultured on agar of $\mathrm{pH} 7 \cdot 4$, was indicated by the fact that such organisms grew when replated on alkaline agar. A more detailed experiment on this point is shown in Table 5. Resistant cultures of the organism were serially subcultured 6 times at $\mathrm{pH} 7 \cdot 4$, and the effect of $\mathrm{pH}$ on the growth of these subcultures was tested. There was no loss of alkali resistance during growth at $\mathbf{p H ~} 7 \cdot 4$. Indeed, the $T_{0.4}$ values at $\mathrm{pH} 9.5$ and especially at $\mathrm{pH} 10.0$ for three of the four

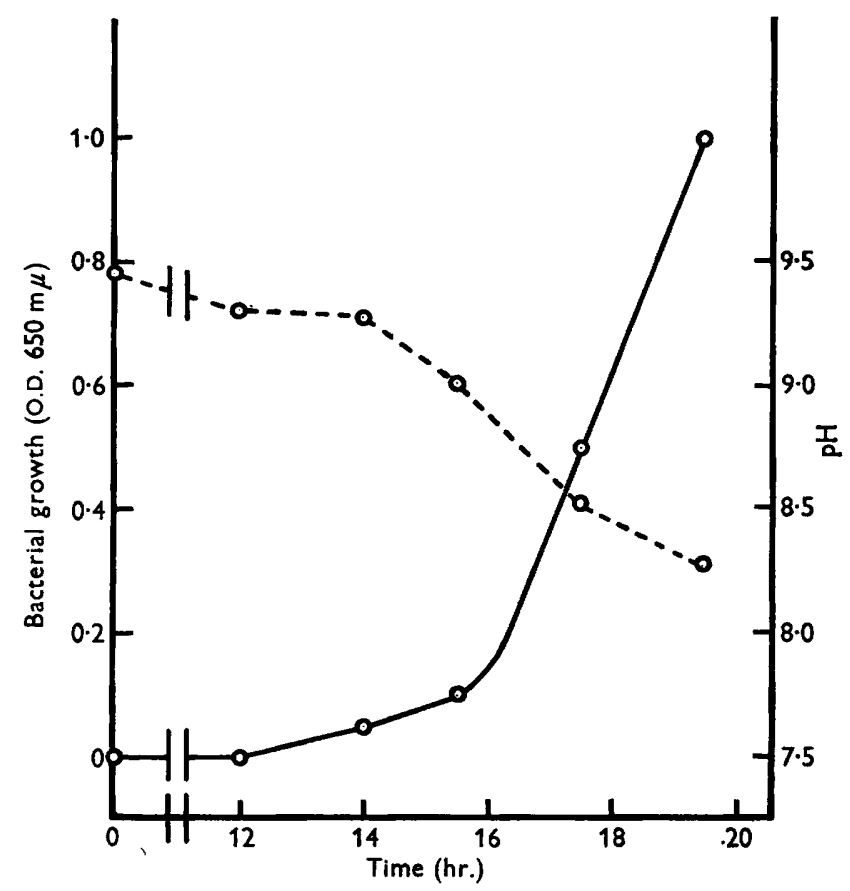

Fig. 4. Changes in pH during growth of sensitive bacteria in alkaline medium. Conditions and legend as in Fig. $3 a$ except that a $4.4 \mathrm{mg}$. inoculum of sensitive organisms was used and the pH was not held constant.

Table 5. Retention of alkali resistance during subculture on agar of $\mathrm{pH} 7 \cdot 4$

$$
T_{0 \cdot 4}(\mathrm{hr} .)
$$

No. of subcultures

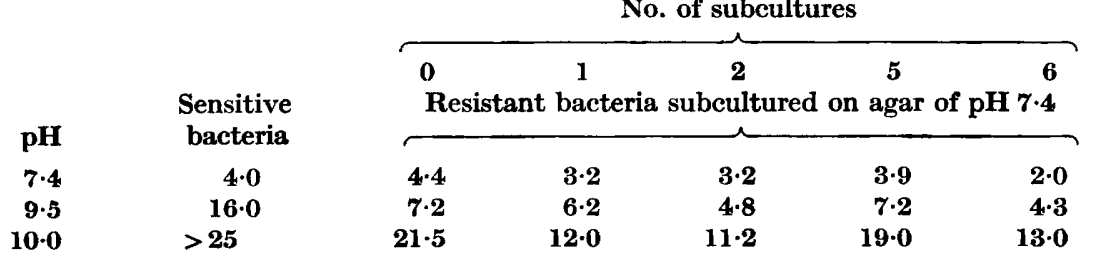

A $0.28 \mathrm{mg}$. inoculum of bacteria was used in each experiment. Resistant $B$. cereus had been maintained previously on agar of pH 10.3, and was serially subcultured on buffered agar of $\mathrm{pH} 7.4$ at $24 \mathrm{hr}$. intervals. The 5 th subculture was stored overnight at $5^{\circ}$ before testing. Growth medium for testing pH sensitivity was nutrient broth + phosphate buffer. 
subcultures tested were lower than those of the parent culture. It may be significant that the one member of the series shown in Table 5 virtually indistinguishable from the parent culture had been held overnight in the cold before testing, but these findings have not been further investigated.

\section{Lecithinase production by resistant bacteria}

Because of the possibility that the lecithinase which is produced by normal Bacillus cereus plays a part in its pathogenicity to insects (Heimpel, 1955 $b$; Kushner \& Heimpel, 1957), the ability of resistant $B$. cereus to produce this enzyme was measured. The resistant organisms when grown in unbuffered $2 \%$ $(w / v)$ casein hydrolysate produced amounts of lecithinase comparable to those produced by a normal culture of sensitive $\boldsymbol{B}$. cereus.

\section{DISCUSSION}

In considering alkali resistance it is natural to refer to the work already carried out on the nature and development of drug resistance in bacteria (reviewed, for example, by Bryson \& Szybalski, 1955; Davis, 1957; Schnitzer \& Grunberg, 1957). However, two differences must be noted between drug resistance and the resistance to alkaline $\mathrm{pH}$ values described here. First, with alkali resistance one is not dealing with a chemical compound foreign to the cell but simply with an excess concentration of hydroxyl ion. Secondly, a drug may affect or be thought to affect only one enzyme, but $\mathrm{pH}$ changes might affect the action of many enzymes.

Since such a general inhibitor as $[\mathrm{OH}]$ is involved we may, at the start, rule out two theoretical mechanisms of resistance. Neither the formation of some metabolite in sufficient concentrations to overcome a specific metabolic block produced by a high $\mathrm{pH}$ value, nor the production of alternative metabolic pathways to circumvent such a block appears to be likely. The role that acid production by the growing bacteria plays in overcoming the toxic effects of high $\mathbf{p H}$ values deserves special consideration, and it seems important to distinguish between what may be termed primary and secondary mechanisms of resistance. If acid production were completely responsible for resistance, then we would expect the resistant inoculum to lower the $\mathrm{pH}$ value of the medium before growth began. This, however, did not occur. Except for a slight fall, found even in the absence of bacteria, the decrease of $\mathrm{pH}$ value accompanied, but did not precede, growth. When the $\mathrm{pH}$ value was maintained by periodic additions of alkali, growth still took place, though at a lower rate than in media of decreasing $\mathrm{pH}$ value. It should be noted that sensitive

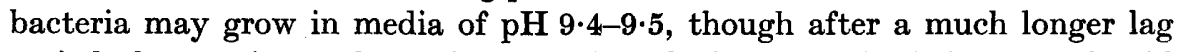
period than resistant bacteria, and that during growth their rate of acid production is much the same as that of the growing resistant bacteria. Resistant bacteria, then, are distinguished from sensitive bacteria not by their ability to produce acid during growth in alkaline media but by their greater ability to begin to grow in these media. Acid production by the growing bacteria may be regarded as a secondary mechanism of resistance, which increases the rate 
of growth once this has begun. It is this acid production that appears responsible for the fact that growth curves in media of initially different $\mathrm{pH}$ values differ mainly only in the length of the lag period.

Different possible primary mechanisms of resistance, which might enable resistant organisms to begin growing in highly alkaline media, have been considered. One possibility is that the resistant organisms have a limited permeability to hydroxyl ion or have an active mechanism that regulates the passage of hydroxyl ion into the cell. If either of these mechanisms were in operation, then a marked difference between intra- and extracellular $\mathrm{pH}$ might occur. In this case, individual enzymes in intact resistant cells might be less affected by external alkaline conditions than the same enzymes in intact sensitive cells. This possibility should be open to direct investigation.

Another hypothetical possibility is that of a shift in the $\mathrm{pH}$-activity curves of several enzymes in the resistant cell. Kocholaty \& Weil (1938) and Kocholaty \& Hoogerheide (1938) noted a shift toward the acid side of extracellular proteinase produced by Clostridium histolyticum and of several dehydrogenases in C. sporogenes as these organisms were grown in more acid media. A similar shift in $\mathrm{pH}$-activity curves towards the alkaline side is conceivable in alkaliresistant Bacillus cereus.

The detailed genetic aspects of alkali resistance have not yet been studied. Resistance appears to be a heritable property, transmitted from subculture to subculture, and persisting in neutral media. Its slow and gradual development suggests that resistance to the highest alkalinities does not arise through selection of a few resistant organisms originally present in the sensitive population, nor through a single-step mutation. A series of mutations, each leading to slightly increased resistance, might be involved. As Bryson \& Szybalski (1955) pointed out: 'In a strict sense, proof that clones of drug-resistant cells depend in origin upon mutation can be supported only by genetic tests, for example, study of bacterial recombination, transduction, transformation, or analysis of the segregation of nuclear hereditary determinants.' This statement must apply as well to any genetic interpretation of our results.

We are indebted to Dr S. G. Smith for first suggesting this line of approach to the problem of increasing pathogenicity. Dr T. A. Angus provided invaluable assistance in examining our bacteria and in discussing changes in microscopic and colonial morphology. We have to thank Dr A. M. Heimpel for valuable discussions.

This paper is contribution No. 505, Forest Biology Division, Science Service, Department of Agriculture, Ottawa, Canada.

\section{REFERENCES}

Bryson, V. \& Szybalski, W. (1955). Microbial drug resistance. Advanc. Genetics, $7,1$.

Davis, B. D. (1957). Physiological (phenotypic) mechanisms responsible for drug resistance. CIBA Foundation Symposium on Drug Resistance in Microorganisms, Mechanisms of Development, p. 165. Eds. G. E. W. Wolstenholme and C. M. O'Connor. London: J. and A. Churchill Ltd. 
Downie, A. W. \& Cruickshank, J. (1928). The resistance of Streptococcus faecalis to acid and alkaline media. Brit. J. exp. Path. 9, 171.

Gale, E. F. (1948). The Chemical Activities of Bacteria. New York: Academic Press Inc.

Heimpel, A. M. (1954). A strain of Bacillus cereus Fr. and Fr. pathogenic for the larch sawfly, Pristiphora erichsonii (Htg.). Canad. Ent. 86, 73.

Heimpel, A. M. (1955 a). The pH in the gut and blood of the larch sawfly, Pristiphora erichsonii (Htg.), and other insects with reference to the pathogenicity of Bacillus cereus Fr. and Fr. Canad. J. Zool. 33, 99.

HeIMPEL, A. M. $(1955 b)$. Investigations of the mode of action of strains of Bacillus cereus Fr. and Fr. pathogenic for the larch sawfly, Pristiphora erichsonii (Htg.). Canad. J. Zool. 33, 311.

Heimper, A. M. \& Angus, T. A. (1958). Recent advances in the knowledge of some bacterial pathogens of insects. Proc. 10th Int. Congr. Entomol. Montreal (1956) 4, 711 .

Kocholaty, W. \& Hoogerheide, J. C. (1938). Studies of the metabolism of the strict anaerobes (Genus: Clostridium). I. Dehydrogenation reactions by suspensions of Clostridium sporogenes. Biochem. J. 32, 437.

Kосноlaty, W. \& WeIL, L. (1938). Enzymic adaptation in Clostridium histolyticum. Biochem. J. 32, 1696.

Kushner, D. J. (1957). An evaluation of the egg-yolk reaction as a test for lecithinase activity. J. Bact. 73, 297.

Kushner, D. J. \& Heimpel, A. M. (1957). Lecithinase production by strains of Bacillus cereus Fr. and Fr. pathogenic for the larch sawfly, Pristiphora erichsonii (Htg.). Canad. J. Microbiol. 3, 547.

Schnitzer, R. J. \& Grunberg, E. (1957). Drug Resistance of Microorganisms. New York: Academic Press Inc.

Staudenmayer, T. (1940). Die Wasserstoffionenkonzentration der Insekten. Anz. Schädlingsk. 15, 114.

StePhENS, J. M. (1952). Disease in codling moth larvae produced by several strains of Bacillus cereus. Canad. J. Zool. 30, 30.

Topley and Wilson's Principles of Bacteriology and Immunology (1955). (4th edition, p. 84. Eds. G. S. Wilson and A. A. Miles. London: Edward Arnold.

UMBreIT, W. W. (1951). Significance of autotrophy for comparative physiology. Bacterial Physiology, p. 566. Eds. C. H. Werkman and P. W. Wilson. New York: Academic Press Inc.

Waterhouse, D. F. (1949). The hydrogen-ion concentration in the alimentary canal of larval and adult lepidoptera. Aust. J. Sci. Res. B, 2, 428. 